\title{
Planning for military real estate conversion: collaborative practices and urban redevelopment projects in two Italian cities
}

\author{
Davide Ponzini ${ }^{\mathrm{a} *}$ and Marco Vani ${ }^{\mathrm{b}}$ \\ ${ }^{a}$ Department of Architecture and Urban Studies, Politecnico di Milano, Via Bonardi 3, 20133 \\ Milano, Italy; ${ }^{b}$ Department of Design and Planing in Complex Environments, IUAV, 30125 Venezia, \\ Italy
}

\begin{abstract}
Despite the fact that the strategic dismissal of a number of military bases has been affecting contemporary urban and rural areas and becoming a new challenge for city planning and policy-making, little attention has been paid to this complex topic at an international level. Several authors have suggested that collaborative planning processes are crucial for the success of military real estate conversion. This article analyzes the Italian policy for the alienation and leasing of public real estate between 1997 and 2012 through the analysis of two projects whose focus was on military real estate in central Italy. This analysis shows why collaboration was not able to solve the significant urban challenges related to the conversion of these areas. The authors suggest taking national policy and local variables and solutions into further consideration (e.g. the quality and design of the physical environment, the policy tools available in the potentially conflictual institutional setting of military base conversion) rather than considering the collaboration with the local community alone.
\end{abstract}

Keywords: urban planning; military real estate; military base conversion; public participation; Italy

\section{Introduction}

Recent global politics has witnessed the end of two contrasting (capitalist and communist) power blocs and the transformation of traditional and conventional warfare. Despite the fact that the strategic dismissal of a number of military bases has been affecting contemporary urban and rural areas and creating new challenges for city planning and policymaking, little attention has been paid to this complex topic at an international level. The aim of this article is to discuss the complex topic of military real estate conversion from a planning perspective and to stress the implications for recurrent collaborative positions in this field. In order to do so, the second and third sections of the article illustrate how the problem of converting military real estate has been depicted in the literature of different disciplines and how, in some cases, collaborative practices were proposed as a panacea despite previously standing criticism. In the fourth section, the article critically reviews the literature regarding collaborative planning approaches and exposes several theoretical criticisms that are relevant to the topic of military real estate conversion. The fifth section investigates the recent policy initiatives related to military real estate conversion in Italy, while in the sixth section analyzes two case studies in central Italy (Bologna and Piacenza), by highlighting the little impact that participation strategies have had. In this sense, the article provides a critical insight into the process of military real estate conversion in contemporary Italy with specific focus on participation. This article

*Corresponding author. Email: davide.ponzini@polimi.it 
acknowledges the fact that military real estate properties may significantly vary in their features and could require different policy approaches and practices, including participation, to begin and sustain their conversion process. At the same time, the significant theoretical and practical limitations of collaborative planning approaches suggest that one cannot normatively adopt and generalize participation as a viable and effective solution. Conversely, other contextual factors are highlighted with reference to the Italian case studies: the crucial function of policy tools and procedures and their relevance in defining political and economic conditions (which may eventually include conflicts), the reduction of uncertainty among key players, the relevance of the design for specific sites, and their use in forecasting actual development opportunities.

\section{The problem of military base conversion in contemporary cities}

The problem of converting underused military bases, and more generally, of military real estate in the urban environment, is quite complex and multidimensional. In fact, because of their function, military sites often host large-scale and peculiar facilities and infrastructures which, in some cases, can be heavily polluted as a result of the activities performed on these areas. In this sense, the costs for conversion can be significantly higher than other comparable areas in contemporary cities, such as post-industrial sites. These areas are often quite large and separated from the civil city fabric. Because of the current situation regarding state restructuring and the critical conditions of public finance, these areas are often at the center of entangled political processes in which the national government expects to derive significant resources from real estate dismissal and conversion while the local community (and political representatives) must cope with the loss of significant jobs and spillover economic effects or expects the immediate reappropriation of the abandoned areas (Ponzini and Vani 2012).

Due to the current changes in geopolitics, warfare technologies, the management of military forces, and the localization and functionality of military bases, this problem systematically affects cities by raising new issues regarding city planning and policymaking in most countries in the Western World and beyond (Brozska, Kingma, and Wulf 1995; Graham 2010). The definition and handling of military base conversion have involved various disciplines, such as political science, geography, economics, and so on. The problem has not been perceived as an important issue in urban planning research and it has not been given consistent and specific coverage. For this reason, it is not possible to make reference to a homogeneous corpus of literature, but rather juxtapose relevant questions, information, and similar positions from different research fields, drawing on accredited academic research, policy reports, and more general inquiries.

One can begin by highlighting the most commonly discussed themes. The convergence of dismissal and conversion policies with a number of other urban and regional policies (see Szelinski 1997; Hansen 2004) seemed crucial in order to attract potential local and private interests in the acquisition, and redevelopment of the areas to undergo significant transformation and potential economic and social appreciation (Holman 2001). Because of their dimensions and conditions, one of the primary issues in military base conversion or reuse policies is related to the high costs of cleaning up the contamination or pollution of these areas (Bearden 2005). Besides remediation and environmental protection policies, the conversion of military areas generally requires investments toward the infrastructure, public facilities, and services that, in times of public finance retrenchment, could make use of joint public-private interventions. 
Furthermore, the integration of conversion plans with other development policies seems reasonable, although it may generally be characterized by the procedures and restraints that typically could reproduce these given power structures. With regards to the cutbacks in military spending and recovery strategies, Bremen and Hampton Roads illustrated how conversion planning was heavily constrained within a sociopolitical and institutional context (Accordino and Elsner 2000).

Economic and local development literature discussed the many instances in which military bodies are capable of influencing political constituencies at various levels. The support given to local economies often turns into a simple pork-barrel dynamic (Coulson 1995; Warf 1997; Sorenson 1998; Zimmer 2004).

Conversely, planning literature considers specific cases of the reuse of military sites in contemporary cities as generally assuming them as being new opportunities for urban redevelopment. Few authors have tried to consistently provide answers to more general and typical questions of military real estate conversion in contemporary cities. For example, Doak (1999) highlighted a number of critical questions regarding the spatial characteristics of military sites, the relationships between public and private interventions, the definition of conversion policy tools, and their integration in the local planning system and its procedures.

Most of the cases that could be found in literature dealt with simplified urban situations that typically evolved into a partial success which was often generalized into broader explicatory theories. These cases almost exclusively referred to large sites or bases with a single location and without significant problems related to their morphology. We acknowledge Joe Doak as one of the few authors discussing this dimension.

The closure of military bases clearly has major land-use implications, particularly in parts of the country where there has been a historic concentration of military use. The land use implications are also emphasized by the spatial and physical diversity of the estate. (Doak 1999, 211)

Following the general considerations in cleaning up polluted brownfields and derelict sites, one may question whether the decontamination of scattered military posts seems to be more difficult when compared to the commonly considered cases. Also, one may note that the dimensions and localization of converting these areas are to be considered as well. The conversion and the subsequent involvement of private developers in large areas may be easier than in scattered areas. Similarly, the value of land in relation to the localization of these military estates may be crucial with reference to their attractiveness for investors and developers. Furthermore, the limitations due to historic preservation and regulation may be interpreted as a disincentive.

The discussion of how conversion policies have been shaped in specific countries seems relevant in order to analyze the policy mechanisms and the key factors involved. The specific characteristics of a planning system may influence the conversion process since, in many cases, the role of national and local institutions and social factors; the material and legal resource distribution; and the policy tools available can determine noncollaborative processes and eventually conflict-inclined situations (Ponzini 2008c). For example, the typical conversion process of US military bases is often taken as a frame of reference for this debate. In this context, the financial resources derived from selling and redeveloping land are often reinvested in infrastructures, public facilities, and services. The fact that this reinvestment may not occur and that the goal of maximizing the revenue derived from military base closures (typical of the central government) may contrast with 
economic development and social cohesion (typical of local actors) is rarely considered. The analysis of the Italian case studies will be discussed through the analysis of their planning framework, their available policy tools, and the involved actors' goals.

\section{Collaborative planning approaches to military real estate conversion}

In several publications related to military real estate conversion, the participation of local communities is depicted as a key element in successful recovery processes. For example, Catherine Hill (2000) analyzed the redevelopment process of the Truman Annex in Key West, FL, USA, and came to the conclusion that creating mechanisms for public participation is crucial in solving typical contrasts among stakeholders and the local community. Other planners more specifically suggested to face such problems by including various other factors in order to implement a wider range of knowledge and values in the development of plans and projects; for example, Van Driesche and Lane (2002) made a discussion along these lines regarding the planning process for future use and management of a former military property in Wisconsin. We do not doubt that within these given contextual conditions, a similar collaborative approach may work out participative solutions, but one may also question whether, in general terms, these may simply solve the pressing problems in military real estate conversion that were mentioned above.

An insightful paper written by Samer Ghaleb Bagaeen (2006) illustrates the limits of collaborative planning theories applied to the issue of military base conversion. It analyzes the case of Omega base, in Warrington, between Manchester and Liverpool, UK, showing the environmental sustainability features of the master plan and the case of the recent redevelopment of the military base in Vauban, near Freiburg in Germany, explaining how community involvement was carried out and contributed to the success of the planning process. The author then expects to have similar findings in redevelopment projects near Amman and Zarqua, in Jordan, but he emphasizes the fact that in both cases:

... nothing about how sustainable both projects are in terms of density, walkability, response to site conditions, community involvement and stakeholder dialogue, or whether the costs and viabilities of different formal solutions had been investigated. (Bagaeen 2006, 348)

Nonetheless, Bagaeen's conclusion does not consider the difference in the real conditions in planning and applies a normative theory, transferring the findings from European cases of redevelopment to the rest of the world:

'Public participation must become the other critical building block to mounting community support for sustainable development, and implementing complex projects at any geographic scale' and 'Building consensus must also be a development priority; redevelopment must [...] be supported by the local community.' (Bagaeen 2006, 351)

The issue of the reuse of derelict sites has been recently analyzed with reference to power distribution, stakeholder empowerment, and public participation (Ambrosino and Andres 2008; Andres 2013). Military real estate does not easily match the basic conditions of typical abandoned urban spaces where the shortcomings of traditional planning could simply encourage temporary uses and public participation. Far from being characterized as 'differential spaces' that are subject to local community appropriation, military bases, after the moment in which their original activities are interrupted, do not generally allow loosely planned processes or open-ended transformation trajectories. In fact, the reuse of 
such sites derives from long-term national policy and redevelopment uncertainties resulting from land characteristics (e.g. heavy pollution, higher costs for conversion, physical dimension, and morphology). Military bases are often physically and symbolically disconnected from both the urban everyday life and often outside of the local planning authority jurisdiction.

Besides these criticisms, one can see that more general theoretical limitations of collaborative planning approaches may affect the abovementioned positions regarding military real estate redevelopment. For this reason, a critical review of relevant theoretical features of collaborative planning is proposed before presenting the Italian case studies.

\section{Collaborative planning theory: relevant approaches and limitations regarding military base conversion}

There is no doubt that collaborative approaches to planning have been successfully spreading in many fields and national contexts. Among many contributions, Patsy Healey's (1997) book is one of the most cited in current planning literature. The most prominent planning schools and research centers in Europe have recognized significant innovation in this approach and have been following it in countless educational and research activities (one may cite the Association of European Schools of Planning or the European Urban Research Association); a set of planning journals and publications developed more or less tacitly along the same lines (among journals one can mention Planning Theory or Planning Theory and Practice). The book has been translated into different languages and transferred into distant national contexts, sometimes resulting in simplification or even misinterpretation in describing and interpreting various challenges encountered in urban and regional planning (Healey and Upton 2010).

Among the theoretical roots, the so-called communicative turn in planning and policymaking was intentionally conceived and promoted in order to respond to the limitations and ineffectiveness of rational top-down planning and to curtail the either technocratic or authoritative role of experts in planning processes. Elaborating on Habermas' theory, the importance of communicative action has been stressed in urban planning and in reaching agreements over planning activities (Innes 1995, 1996; Healey 1997, 2007; Innes and Booher 1999). This approach has an articulated background and evolution that cannot be explored in such a short paper (see among others: Forester 1985, 1989, 1993; Sager 1994).

A selected set of references will be used in order to show relevant criticisms and to set the ground for discussing the abovementioned military base conversion issues. According to Beauregard (2005), some collaborative approaches propose a normative theory about how planners should work rather than analyzing and interpreting what they actually do. This set of theories tends to stress the role of the planner as a mediator and facilitator instead of focusing on what actually happens or has to be done in facing collective urban and regional issues or opportunities. Susan Fainstein $(2000,455)$ rightly brought attention to the risk of the tendency to 'substitute moral exhortation for analysis' and to paying limited attention to the final outcome and benefit distribution among different social groups (Fainstein 2005). The substitution of scientifically formulated knowledge with the discovery of problems and solutions through communicative planning practices can sometimes be considered mainly as a way for forging consensus despite unequal outcomes in the planning process (White 1996).

Despite the aim at providing planners and decision makers with substantial and effective knowledge of urban and social problems, collaborative approaches typically 
tend to address procedural and management expertise (Vettoretto 2003). In fact, the focus of collaborative planning has been the process and its potential reforms rather than the object of planning: the development and transformation of cities, regions, or parts of either. Despite recent interest in the quality of places (Healey 2010), collaborative approaches have generally been paying limited attention to the physical, morphological, and typological dimensions of urban issues, concentrating more on governance and symbolic and discursive aspects (Palermo and Ponzini 2010).

Generally, the interpretation of urban transformation processes is unfoundedly irenic. In fact, collaboration is assumed to be possible since actors have interests that may not be fixed and may consequently change their frames of reference in public decision-making. Social and economic conflicts, lock-ins, and impasses in decision-making - regarding the development or transformation of one area or regarding the strategic plan for a city or the spatial development vision of one region - seem not so widespread or relevant in the collaborative approach (Brand and Graffikin 2007). The actual influence of embedded economic interests, political power, urban regimes, and conflicts is underestimated (Huxley and Yiftachel 2000). These criticisms seem extremely relevant regarding the issue of military base conversion.

Mazza (2004) explained that open dialog among different parties contributing to city planning may not occur since some of them prefer to maintain asymmetric positions in terms of power, resource distribution or investment, allocation of time, or information disclosure. It is certain that negotiations may, in many cases, ameliorate decision-making processes, but one may question whether or not this dialog will impede socially unbalanced decisions, inconclusive plans, and projects or crucial implementation problems. Furthermore, planning processes may not match elementary conditions for which collaboration could be possible. For example, where negotiations tend to be undertaken and be successful in close networks (Allmendinger 2001) when actual policy tools are uncertain, when the needed resources for allowing projects to take off are not available, and when key actors have mutually exclusive goals, planners may have a marginal role and limited opportunity to influence the process (Palermo and Ponzini 2010).

Reasonable doubts have arisen with regards to the gap between collaborative theorizing and planning practice and whether they should push the planning debate to reconsider the generalizability given to such positions. More specifically, the criticisms regarding collaborative planning approaches might be traced back to the fact that they consider the conditions of a limited group of political, institutional, and planning systems in a particular historic phase, and they expect to transfer planning knowledge and guidelines to distant contexts (Healey and Upton 2010). As mentioned in section 1, we believe these conditions to be particularly important regarding issues related to military real estate conversion.

Patsy Healey (2003) partially replied to these and other critics and suggested how to improve collaborative planning knowledge. More specifically, Healey views the Habermasian criteria for ideal speech situations as being aids for planners to critically interpret their own situation in planning practices rather than conditions (Tewdwr-Jones and Allmendinger 1998). She agreed upon the fact that context is determinant and that innovations in planning are to be searched for in fine grain interactions, rather than in socioeconomic or institutional structures. In her view, the attention given by the structuration theory to urban processes is sufficient in analyzing power, as well as discourses, and to finally give norms to planning practices. The final remark in the 2003 article specifically addresses the circulation and the potential misinterpretation that collaborative planning can induce in different contexts. Furthermore, the author pleaded for more research 
focusing on specific contexts, planning failures, and the opportunity for small advancement in theory and practice. In this sense, we can find a substantial agreement regarding the limitations of this planning theory and the caution that must be paid while discussing a complex planning issue such as military real estate conversion.

Two Italian processes of military real estate conversion are considered in the light of long-term policy reform and the relevant policy and planning tools available.

\section{Military real estate conversion processes in Italy, 1997-2012}

This section of the article describes the institutional frame and the policy undertaken by the Italian Government during the last 15 years for converting and putting public real estate on the market. The question of the reuse of the real estate divested by the Italian State, among which military bases and facilities, has been at the center of the public debate for some time (for an extensive analysis, see Ponzini 2008b). The reasons why the Italian Government had been looking into selling or leasing public real estate to the private sector depended on the necessary reduction of public expenditure while being part of the European Monetary Union. Currently, these initiatives have been explicitly addressing objectives of a more efficient management for public real estate properties, and of starting urban regeneration and local development processes.

Since the beginning of 1990 s, the Italian Government has created a number of public, semipublic and private agencies dedicated to the selling or leasing of public real estate (Decrees 35/1992 and 86/1994). These initiatives have had little or no impact at all for some time. As a part of a broader privatization process (Ponzini 2008a, 2010), in 1997, the Italian Government undertook other initiatives for the alienation and securitization of underused public real estate. The Decree 127/1997, the Decree 191/1998, and the Financial Bills (Decree 448/1998 and Decree 488/1999) introduced the possibility of alienating most of the publicly owned real estate, but they were not applied because of the inadequacy of information regarding the extent and value of the public patrimony (Parlato and Vaciago 2002). The Agency of State Properties (Agenzia del Demanio - ASP) was created in 1999 to provide information regarding 30,000 real estate assets, and to oversee their rationalization, management, appreciation, and alienation, being articulated region by region. Following the Decree 410/2001, the Company for the Securitization of Public Real Estate (Società Cartolarizzazione Immobili Pubblici) was created for selling a limited number of assets. The following year, the Patrimony Incorporated (Patrimonio Spa) was created with the mission of alienating state-owned assets to finance Infrastructure Incorporated (Infrastrutture Spa). This initiative also suffered dramatic criticisms and was stopped by political and institutional oppositions at all levels. The alienation and securitization of public real estate generated revenues that were well below the Governments' expectations.

Finally, the first set of the extensive public real estate census was available to public institutions and to potential private investors. In the Financial Bill for 2007, the government explicitly included local development through real estate appreciation among the objectives for the ASP - besides the rationalization in property management, and the generation of revenue for decreasing the state's debt. For this reason, the instrument of long-term lease and of Unified Appreciation Programs (Programmi Unitari di Valorizzazione - PUV) was introduced to make private investments economically viable and to integrate other urban interventions involving local government properties. The Financial Bill for 2008 included substantial investments to be locally integrated with the conversion of public real estate, among which were the military sites. 
The ASP real estate database is composed of more than 11,000 entries and refers to a value of $€ 4.7$ billion. The ASP has started to work on 85 initiatives including 238 properties before the beginning of 2010. Successively, approximately 400 properties have been handed from the Ministry of Defense over to the ASP, with an esteemed value of about $€ 2$ billion, among which 148 properties were already included in the appreciation programs. In Italy, besides a number of individual projects (among which the case of Piacenza will be discussed), only four Unified Appreciation Programs were started: Bologna, Ferrara, and the Lazio and Liguria Regions. In 2008, the new government led by Berlusconi implemented a different strategy regarding the sale of public real estate by devolving it to local governments and allowing diverse and ad hoc arrangements with the private sector to be made that will not be discussed in this article. The current devolution toward the local government may apparently simplify the procedures for selling and collecting financial resources for the public sector, yet it runs the risk of inducing processes that are not technically or economically viable. It may also induce very limited opportunities for real estate appreciation and for the creation of new infrastructures and public facilities, due to the oversupply and slowdown in the real estate market (Ponzini and Vani 2012).

On the basis of this review one can argue that, until 2007, the national policy targeted the economic appreciation of public real estate and it has been weak and incapable of developing a viable strategy for military real state conversion. After 2007, the main goal of reducing the public debt was coupled with local development goals, directly involving local governments in order to allow 'ad hoc' arrangements among different administrative levels, which nonetheless produced very limited results. The next chapter describes and analyzes two processes of the conversion of military real estate in two cities in central Italy, Bologna, and Piacenza, while focusing on specific participation practices. The case studies included in this analysis are among the most advanced experimentations in Italy and are, for many aspects, relevant well beyond national boundaries.

\section{Military real estate conversion and public participation: two Italian case studies}

This chapter presents the case studies of Bologna and Piacenza. Both are medium-sized cities in the Emilia-Romagna Region. This provided an easily comparable frame of reference in the face of the variety of Italian cases. In each city, one relevant planning process regarding military real estate conversion is analyzed and the participation practices are described in detail.

\subsection{Bologna: military base conversion and public participation in the structure plan}

In Bologna, the conversion of military real estate has been part of the local government's broader and long-term strategy for infrastructure development, improvement of specialized tertiary functions, and of touristic, research, and educational activities. The agreement signed by the city and the ASP was integrated into the new structural plan (Ginocchini and Manaresi 2008; Gabellini 2010) both in technical and procedural terms, with particular attention to the creation of public services and facilities and establishing few clear principles regarding relevant real estate market trends (Evangelisti 2012).

The core of the process started in the beginning of 2007 when the Agency negotiated the stock of assets with the Ministry and reached an agreement regarding the 20 properties to be included in the PUV and the creation of a task force. In the following year, the new 


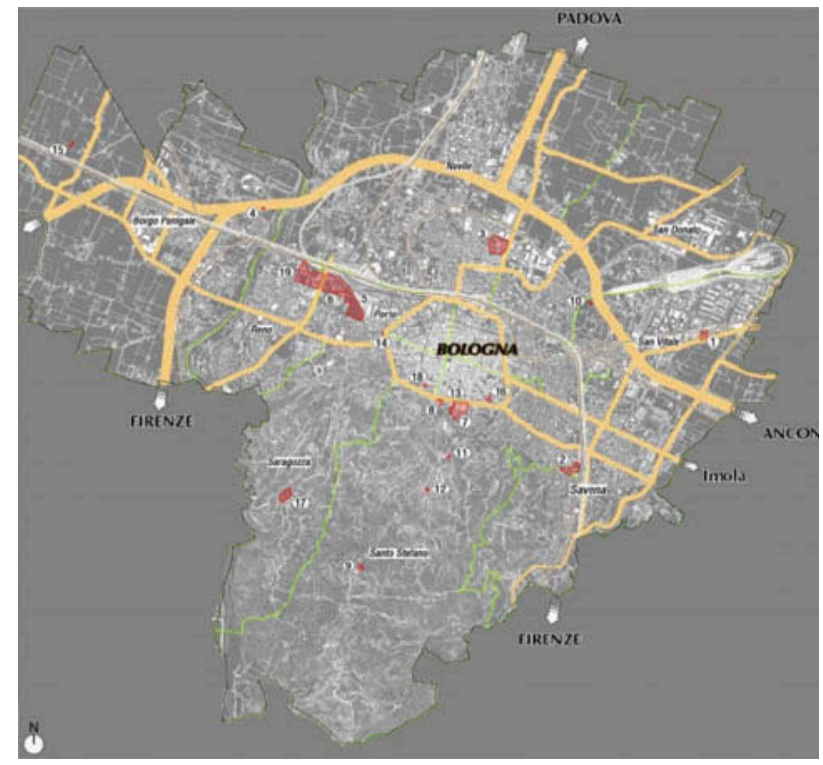

Figure 1. (Colour online) The areas targeted by the PUV in the urban context of Bologna retrieved from the http://www.agenziademanio.it/website.

structure plan had been developed and approved by the city government, and a feasibility study regarding the military areas was commissioned. In this way, the projects that were included in the study could be integrated with other operative planning documents adopted in early 2009: Regolamento Urbanistico Comunale (RUE) and Piano Operativo Comunale (POC), in order to allow the call for private proposals to be issued by the end of the same year, ensuring the coherence with planning and implementation procedures (one of the main concerns of the Agency) (Comune di Bologna 2007, 2009).

The PUV comprises several important properties (overall $80 \mathrm{ha}$ ) for the future redevelopment of a dense city (14,300 ha for about 300,000 inhabitants). The areas to be affected by the program will comprise almost one-third of the amount of real estate to be delivered during the next decade (Figure 1). In particular, the transformations will be scheduled with reference to three main subregional systems. The first is the 'railway city,' including the spaces for public mobility (improving the railway station, airport, and specific office districts). The military properties will consolidate the transformations of the main station, particularly allowing the creation of a park around the Prati di Caprara area and its connection to a broader ecological system. The second system is the 'hill city,' where the historic barracks and fortifications are to be repurposed and appreciated through compatible functions, while other properties will be demolished in order to allow for the development of a set of 'green' and public areas (in particular in the area Sta.ve.co.), and a large public parking lot serving the Rizzoli Hospital. The 'beltway city' will be strengthened through functions and areas that are complementary to mobility such as intermodal areas, parking, and 'green' and agricultural strips.

The process demonstrates the possibility of finding converging objectives between different institutional levels over a complex set of interventions through the definition of a clear spatial vision (Palermo and Ponzini 2012). The city wanted to lead a broad coalition and could provide it with specific technical support and reliable timing for decision- 
making while simultaneously targeting public goals and curbing the opportunities for private real estate appreciation. This rendered the entire operation economically feasible (forecasted real estate value: $€ 96$ million). At the national level, the Agency negotiated the economic compensation for the Ministry of Defense and verified that the correct interventions for the preservation of the properties be applied with the Regional Superintendence of the Ministry of Cultural Heritage. On the heels of personal scandals regarding the Mayor in 2009, the city had been managed by a receiver for more than 1 year, limiting extraordinary measures in the field of urban planning and development and making the final outcome of conversion more and more uncertain. Currently, the public administration is facing the dramatic shortage of financial resources in both the public and private sectors.

If one considers the conversion of a specific site and the relevance of participatory practices, the most intense activity was witnessed in the Sani military warehouse, which is located in the early twentieth century industrial expansion on the east side of the Bolognina neighborhood. The area was planned to undergo significant transformation in compliance with the 'city of the railway' strategy in accordance with the operative plan (POC) defined by the city, due to the enhancement of its accessibility and perhaps to real estate appreciation. Through the POC, the Sani site was interpreted by the public administration as being an opportunity to provide different populations and users with a space for encounters. As part of the broader strategy for public participation in urban planning and urban design promoted by the City of Bologna, the collaborative workshop 'Bolognina Est' started in 2008 in order for the aging local population and the various immigrant populations (having Chinese and North Africans origins in most cases) to relate with one another and discuss the transforming areas in the new Structure Plan. Thanks to the networking with other initiatives at the city level, the workshop leveraged local knowledge and aspirations of existing groups of citizens, associations, and local stakeholders, by articulating participation into plenary sessions and focus groups with selected participants. The informative and urban design materials were provided in different languages in order to include the immigrant population and their discussion was synthesized into specific guidelines for future operative plans. The workshop has been active during the implementation of public investments in order to allow citizens to monitor and discuss the transformations underway with specific reference to public space.

The participatory planning workshop in Bologna can be considered a good means for gathering information and perspectives of the local community and for the experts involved in order to build consensus regarding the objectives and procedures of the conversion. The problems related to the implementation refer mainly to the weak responsiveness of the local investors to public real estate and their tendency of adopting a 'cartel' strategy: a small and cohesive group of developers waiting for more profitable conditions before investing in the redevelopment of the site. In this respect, participation and the correct integration of other public investments in the area were not determinant for starting the conversion. At the same time, one must stress that the care for the alignment of national and local procedures and institutional agenda paid by the actors involved in the Bologna process are important conditions, but not sufficient for its success.

\subsection{Piacenza: military base conversion and participation in an uncertain planning process}

Piacenza has always had an important military role for the region. Its original settlement and subsequent expansions maintained the features of a fortified city and, since the second 
half of 1990s, it was destined to be the Pole for Maintenance for Northern Italy (collecting and maintaining functioning vehicles, equipment, and materials of the army). In current years, the city has been trying to reposition its economy on the basis of innovations in small and medium enterprise activities and in the research and education economy. The city witnessed strong suburbanization trends and real estate market that is affected by a supply surplus and by the reconfiguration of retail properties. The real estate value in the city center has been lowered by these conditions even before the 2009 crisis hit the Italian market.

The city preferred to face the issue of military base conversion by adopting a specific master plan which was separated from the by-law Structure Plan. Selected areas are to be demilitarized, improved, and converted into civil uses in order to generate economic resources for the creation of a new pole to localize military functions under the control of the Ministry of Defense; a number of smaller areas already given to the ASP are to be converted to civilian functions. The first portfolio is a heterogeneous set of properties, including railway infrastructure, historic buildings, warehouses, and several smaller areas having the overall dimension of about 100 ha.

Since 2003, this issue has been politically significant for the number of jobs related to the military base and was included in different processes of spatial planning and visioning and public participation activities (e.g. Patto per Piacenza, Piacenza Vision 2020; Piacenza e il suo futuro; Pianificare Piace, see Pasqui, Armondi, and Fedeli 2010) that produced information and interpretations to be used in the local Commission for Military Base conversion. An initial agreement between the Ministry, the Agency, and the local government was signed in early 2008 envisioning the transfer and the definition of a program for appreciating an overall area of $760,000 \mathrm{~m}^{2}$ in order to generate $€ 223$ million. These expectations were difficult to meet without inducing critical effects in the development of the city, if not impossible given the real estate market conditions (DiAP 2010). For these reasons, the master plan was used by the local administration to provide the areas with a morphological scheme. The conversion of the areas seems to have entered an impasse that was complicated in 2008 by the mentioned change of procedures at the national level (Pasqui 2012) (Figure 2).

The central Pertite area was an ammunition depot and in the last decade it has been at center stage in the public debate for the future of the city (Castellini and Cavalli 2009).

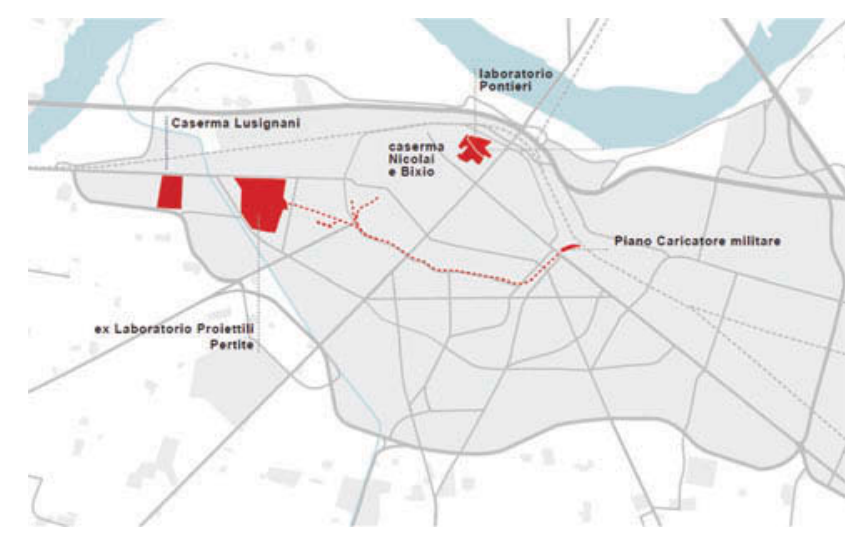

Figure 2. (Colour online) The areas targeted by the Master Plan in the urban context of Piacenza. Retrieved from http://www.comune.piacenza.it. 
The area was targeted by the 2001 mayoral electoral campaign, as well as by several participatory programs for elementary school students promoted by the Provincial Government in 2008. Since 2009, the association 'Friends of Pertite' claimed the conversion into a park and lobbied for it by mobilizing the public opinion and without assuming radical positions.

The design of the new Structure Plan for the city became the occasion for the 'Friends of Pertite' to promote the area as a part of a larger 'green' system, linking the park areas of the Trebbia and Nure rivers, the parks of Montecucco, Galleana, Polisportivo, Madonnina, Farnesiana, and Montale. This idea of constituting a 'green belt' emerged in the negotiations for the conversion of military areas between the city government and the Ministry. The costs of the complex operation or relocation of the army in the city and in Northern Italy made this hypothesis not viable, as well as the less costly opportunity of converting green fields into new military settlements was opposed by environmental activists specifically because this solution would have destroyed the 'green belt' system and its continuity.

The heavy pollution and the discovery of illegal dumping of toxic materials and the lack of opportunities for discussing the overall presence of the military forces in the city generated an impasse. On the one side, the Ministry was afraid of being required to depollute the area (estimated costs: $€ 15$ million), on the other side, despite their participation attempts, the city could not drive the debate and the political consensus in such a difficult operation, which was only partially considered in the Structure Plan to be designed at that time.

When the national framework for the conversion of military bases was changing in the years 2009 and 2010, the Ministry proposed to concentrate new military functions in the Pertite area. This raised the opposition of local groups who joined in the 'Friends of Pertite' which was finally supported by some 10,000 people and organized a series of initiatives such as public hearings, meetings with experts, spectacles, and the collective 'hug' of 2500 people to the area. This led to a referendum in 2011 in which the proposal of creating a park in the Pertite area received 30,000 positive votes without, however, reaching the needed quorum.

In the case of Piacenza, the framework is unstable in terms of planning tools. The ability to nest the conversion project into a broader vision for the city is evidently more limited than in Bologna. The claims of the local advocacy groups were politically relevant but they did not consider the costs for depolluting the area of Pertite, leading the local administration to an impasse in that project. Moreover, it is clear that core decisionmaking arenas are precluded to local community advocates, while the city administration could not effectively negotiate with the Ministry of Defense because of structurally conflictual objectives.

\section{Analysis and discussion of the two case studies}

This section refers to the participative practices of each of the two cases, to the criticism highlighted in literature as was presented in the fourth section of the article, and finally comments on other relevant planning issues in Bologna and Piacenza (Table 1).

The Bologna and Piacenza experiences are diverse and they allow one to look at the Emilia-Romagna Region as a laboratory for military real estate conversion, with particular reference to urban scale planning and site redevelopment. The limited coordination at the Regional level induced processes that were open and inclusive of different local actors. While the City of Bologna could link the new projects to a long-term structural vision and 
Table 1. Synthesis of the analyzed processes in two areas in Bologna and Piacenza.

Planning and participation in the conversion projects of Caserma Sani (Bologna) and Pertite area (Piacenza)

\begin{tabular}{|c|c|c|}
\hline & Caserma Sani & Pertite area \\
\hline $\begin{array}{l}\text { Surface of the military } \\
\text { property }\end{array}$ & $108,000 \mathrm{mq}$ & $280,000 \mathrm{mq}$ \\
\hline $\begin{array}{l}\text { Surface of the surrounding } \\
\text { target area }\end{array}$ & $220,000 \mathrm{mq}$ & n.r. \\
\hline Location & City center (Bolognina) & City center \\
\hline Legal restrains & Relevant & $\begin{array}{l}\text { Relevant (regarding } \\
\text { pollution) }\end{array}$ \\
\hline Participation & Directly managed by the city & $\begin{array}{l}\text { Spontaneous and } \\
\text { grassroot }\end{array}$ \\
\hline Promoter & Local authority & Citizen associations \\
\hline Strategy & $\begin{array}{l}\text { Institutionalization of the conversion } \\
\text { process }\end{array}$ & $\begin{array}{l}\text { High political pressure, } \\
\text { low information }\end{array}$ \\
\hline Tools & $\begin{array}{l}\text { Open information sessions. workshops; } \\
\text { thematic focus groups and public } \\
\text { events }\end{array}$ & $\begin{array}{l}\text { Public hearings; } \\
\text { referendum; } \\
\text { happenings }\end{array}$ \\
\hline Participants & 400 & $<100$ \\
\hline Formal outcome & Guidelines for the operative plan (POC) & $\begin{array}{l}\text { Political consensus (e.g. } \\
30,000 \text { votes for the } \\
\text { referendum) }\end{array}$ \\
\hline Impacts & $\begin{array}{l}\text { Planning and implementation of projects } \\
\text { related to public spaces and } \\
\text { infrastructure (not of the conversion of } \\
\text { the military property itself) }\end{array}$ & $\begin{array}{l}\text { Keeping the issue in the } \\
\text { political agenda }\end{array}$ \\
\hline
\end{tabular}

n.r. $=$ not relevant

evaluated their sustainability, the process of redesign in the Structure Plan in Piacenza could not really integrate the projects for conversion that came to an impasse. The complexity of such processes and the potential restrictions in such regulative frames induced large operators to exit these processes, and manifest interest for less regulated and more discretional opportunities for real estate development or redevelopment (Gaeta 2010).

Where a clear spatial vision was provided at the urban scale, the Unified Appreciation Programs could coordinate different public and private actors and could jointly program real estate value capture and the localization of new public and private facilities. In the case of Bologna, the ability of harnessing the decision-making within the time frame for the design of the Structure Plan induced, at least, actors with different agendas (and political life cycles) to negotiate. Here we can notice that key actors can nonetheless have mutually incompatible objectives. The ASP was originally instituted to use the real estate revenue for lowering the state's debt, although at the local level, the investment of this revenue seems crucial for enhancing the quality of the area in order to attract private investments. The uncertainty level dropped where the design of conversion programs was integrated with the structure plan, yet participatory practices did not make the difference, since the real estate developers ultimately did not invest. In the case of Piacenza, the city government alone could not manage part of the dynamic of demilitarization and resettlement of national military facilities if the Regional of National Government did not support it. 
Table 2. Synthesis of the two cases of military real estate conversion in Bologna and Piacenza: surface and location data (1); Actor's commitment (2); and planning procedures that were adopted (3).

\begin{tabular}{|c|c|c|c|c|c|c|}
\hline & & \multirow[b]{2}{*}{ Surface } & \multicolumn{3}{|c|}{ Location \% (number of facilities) } & \\
\hline & & & Center & Outskirts & Rural & \\
\hline \multirow[t]{5}{*}{1} & Bologna & 80 ha & $38 \%(6)$ & $61 \%(8)$ & $1 \%(5)$ & \\
\hline & Piacenza & 100 ha & $41 \%(8)$ & $59 \%(3)$ & n.r. & \\
\hline & & \multicolumn{4}{|c|}{ Actors' commitment } & \\
\hline & & & $\begin{array}{c}\text { National } \\
\text { administration }\end{array}$ & $\begin{array}{l}\text { Local } \\
\text { administration }\end{array}$ & $\begin{array}{l}\text { Local } \\
\text { community }\end{array}$ & Consultants \\
\hline & & $\begin{array}{c}\text { Agenzia del } \\
\text { Demanio }\end{array}$ & Ministry of defense & Municipality & & ATI/University \\
\hline \multirow[t]{4}{*}{2} & Bologna & ++ & n.r. & ++ & ++ & -+ \\
\hline & Piacenza & +- & +- & ++ & ++ & ++ \\
\hline & & & Procedure & & & \\
\hline & & & Type & $\begin{array}{l}\text { Relationship } \\
\text { with structure } \\
\text { plan }\end{array}$ & & \\
\hline \multirow{2}{*}{\multicolumn{2}{|c|}{$3 \begin{array}{l}\text { Bologna } \\
\text { Piacenza }\end{array}$}} & & PUV & Paradigmatic & & \\
\hline & & & $\begin{array}{l}\text { Hybrid (master } \\
\text { plan + agreements) }\end{array}$ & Problematic & & \\
\hline
\end{tabular}

It is evident that, in these conditions, collaborative processes had a symbolic importance but did not concretely contribute to the actual conversion of military real estate. The high degree of uncertainty and the contrasting objectives of making projects for the longterm development of one city rather than maximizing the revenue of urban redevelopment (i.e. the goals of the National Agency and the Ministry of Defense) were not effectively solved in the considered cases. Evidently, the goal of reducing the public debt by selling underutilized public assets was not compatible with public intervention and with the internalization of positive effects of urban redevelopment by private developers (Table 2).

The proposed grid reports both spatial and policy features of the two cases. It shows the extension and diffusion of the military areas that are dismissed and to be converted (central - semi central and peripheral zones). It provides a snapshot on the relevance of the areas and buildings in the urban redevelopment strategy in terms of both morphology and legal status and it analyzes the commitment of the urban decision-makers and the relation to formal planning processes and documents.

\section{Conclusion}

The conclusion of this article is two-folded. On the one hand, the issues of the Italian cases can provide the reader with an interpretation of conditions for the reuse of Italian military real estate in the year 2000s. On the other hand, the empirical evidence allows us to show how normative collaborative approaches seem to address points that are not crucial for the specific planning experiences set forth in this article. 
It is clear that Italy has been facing a declining phase in terms of political and public life and in urban policy-making, and one can discuss if this context is an anomaly in the European and western world (Palermo and Ponzini 2012). After 15 years of experimentation in the Italian field of urban policy, one can register the decline of new instruments and the reconfiguration of the urban agenda demonstrating limited innovation (Codecasa and Ponzini 2011). Pasqui (2010) explained this descending phase both in terms of the failed transition of the Italian economic and urban system, and the insufficient contribution of reformist technical and political elite.

In the Emilia-Romagna Region, the approach to conversion attempted to nest the redevelopment projects into actual structure plans at a local level, or direct negotiation between the local government and the ministry. The ground for communicative and collaborative interaction was prepared, but main operative input came from interinstitutional and technical task forces, even when explicit participatory activities were carried out by the local administrations. The attempted inclusion of larger sets of stakeholders was partially successful within the mentioned national policy process, but today it seems to not have any significant impact. Evidently, it is difficult to expect the varied processes of militarization and demilitarization investing Italian cities, the divergent goals of national and local government and unequal distribution of costs and benefits of redevelopment to be ideal conditions for collaboration to influence military base redevelopment, with the exception of discursive and symbolic dimensions.

The cases analyzed in this article are, in our opinion, germane for discussing some of the pitfalls of an approach that systematically exhorts for collaboration in this field. The conversion projects targeted issues of technical, procedural, and financial feasibility and were based on the development of shared visions for the future uses and values of the real estate stocks, avoiding the risk of opportunistic behavior among the key actors (which is considered typical in such conditions, see Vettoretto 2003). The case of Piacenza confirmed the weaknesses of participation in the face of discontinuous public guidance during different political cycles (Allmenginder 2001), the indeterminacy in timing, and final physical and functional outcome with respect to military facilities to be converted and in the relevant urban compounds.

In Bologna, public participation and communication were organized in specific phases and regarding specific elements of the redevelopment project. The hierarchies and roles of key public actors were stable during the process despite the political turbulence at the national and local level. Furthermore, once the program was shared and conflicts were technically resolved, each stakeholder kept its own autonomy of action. The conditions for which public participation contributed to the program can be found in the fact that the PUV was successfully nested into the making of the Structure Plan and the planning team technically explored potential physical, economic, and functional outcome of the PUV. These elements were at stake in promoting participation and in taking into consideration the public input in non-demagogic ways, by envisioning a broader impact over relevant sections of the city. In this sense, Bologna can be considered a paradigmatic case of PUV in the Italian panorama (Evangelisti 2012). In Piacenza, although the Mayor preferred not to connect military base conversion projects with the making of the new Structure Plan, a clear projection of financial and design features of the target areas allowed the conflict between the interests of the Ministry of Defense and the City to emerge. Despite the significant presence of participatory procedures and community mobilization, the city government could not plan and ultimately redevelop properties and locate functions that were required for the conversion and re-localization of new military facilities to be 
economically viable. More generally, the physical dimensions, morphology, and locations of different parcels of military real estate were less of a factor than expected.

Accordingly, we can say that the scope of analysis and the elements to be considered in policy-making with reference to military base conversion is, in practice, much wider than collaborative approaches propose in theory (Bagaeen 2006). Even though it is evident that military real estate properties may significantly vary in their features and generally could require different practices of participation, a set of determinant elements clearly emerged in this article. The crucial function of policy tools and procedures and their relevance in defining political, economic conditions, and lowering uncertainty among key actors; the relevance of physical design explorations for specific sites; and their use in forecasting actual development opportunities costs and benefits (Ponzini 2008c; Gebhardt 2009; Palermo and Ponzini 2012; Pasqui 2012).

The issue of military real estate conversion requires further attention and systematic research both by planning scholars and practitioners.

\section{Acknowledgements}

This article derives from joint research activities undertaken by the authors. However, the first draft version of Sections 1-5 can be attributed to Davide Ponzini, the first draft version of Sections 6-7 can be attributed to Marco Vani, while Section 8 can be attributed to both of them. The authors would like to thank two reviewers of Planning Research and Practice for their valuable comments.

\section{References}

Accordino, J., and W. Elsner. 2000. "Conversion Planning in Two Military Shipbuilding Regions: Hampton Roads, Virginia, and Bremen, Germany." International Regional Science Review 23 (1): 48-65.

Allmendinger, P. 2001. Planning in Postmodern Times. London: Routledge.

Ambrosino, C., and L. Andres. 2008. "Friches en ville: Du temps de veille aux politiques de l'espace: acteurs informels, planification et mutabilité urbaine dans le Quartier Berriat à Grenoble." Espaces et Sociétés 134: 37-51.

Andres, L. 2013. "Differential Spaces, Power Hierarchy and Collaborative Planning: A Critique of the Role of Temporary Uses in Shaping and Making Places." Urban Studies 50 (4): 759-775.

Bagaeen, S. G. 2006. "Redeveloping Former Military Sites: Competitiveness, Urban Sustainability and Public Participation." Cities 23 (5): 339-352.

Bearden, D. M. 2005. "Military Base Closure: Role and Cost of Environmental Clean Up." CRS Report for Congress, April. New York: US Department of State, Foreign Press Center.

Beauregard, R. A. 2005. "Introduction: Institutional Transformations." Planning Theory 4 (3): 203207.

Brand, R., and F. Graffikin. 2007. "Collaborative Planning in an Un-Collaborative World." Planning Theory 6 (3): 283-313.

Brozska, M., K. Kingma, and H. Wulf. 1995. "Demilitarization and Conversion of Military Structures." World Social Summit. Copenhagen.

Castellini, V., and G. Cavalli. 2010. C'è un bosco in città? Partecipazione, memoria ed immaginario. L'area Pertite tra presente e futuro. Report, IUAV Program in Public Participation and Local Policy. Venice: mimeo.

Codecasa, G., and D. Ponzini. 2011. "Public Private Partnership: A Delusion for Urban Regeneration? Evidence from Italy." European Planning Studies 19 (4): 647-667.

Comune di Bologna. 2007. "Dagli edifici dismessi la nuova spinta allo sviluppo." Edilizia e Territorio 45: 22-25.

Comune di Bologna. 2009. Bologna: Leggere il Nuovo Piano Urbanistico: PSC + RUE + POC. Ferrara: Edisai.

Coulson, M. 1995. "The Geography of Defence - Developing Themes of Study." GeoJournal 36 (4): 371-382. 
DiAP [Dipartimento di Architettura e Pianificazione del Politecnico di Milano, Laboratorio di Progetti e Politiche per il Territorio] 2010. Masterplan per le Aree Militari di Piacenza. Primo Rapporto: Esplorazioni e Scenari. Milan: Mimeo. http://web2.comune.piacenza.it/ territorio/psc/pscdocumento-preliminare/allegato-2-masterplan-aree-militari.

Doak, J. 1999. "Planning for the Reuse of Redundant Defence Estate: Disposal Processes, Policy Frameworks and Development Impacts." Planning Practice and Research 14 (2): 211-224.

Evangelisti, F. 2012. "Bologna: Un campo di sperimentazione tra Psc e Puv." Territorio 62: 22-28.

Fainstein, S. S. 2000. "New Directions in Planning Theory." Urban Affairs Review 35 (4): 451-478.

Fainstein, S. S. 2005. "Planning Theory and the City." Journal of Planning Education and Research 25 (2): 121-130.

Forester, J. 1985. Critical Theory and Public Life. Cambridge: The MIT Press.

Forester, J. 1989. Planning in the Face of Power. Berkeley: University of California Press.

Forester, J. 1993. Critical Theory, Public Policy, and Planning Practice. Toward a Critical Pragmatism. Albany: State University of New York Press.

Gabellini, P. 2010. Fare Urbanistica. Esperienze, Comunicazione, Memoria. Roma: Carocci.

Gaeta, L. 2010. "Riflessioni sull'accordo pubblico/privato a partire da un caso piacentino." XXIII Conferenza Nazionale Società Italiana degli urbanisti. Rome: Università degli Studi Roma Tre.

Gebhardt, M. F. 2009. "Politics, Planning and Power: Reorganizing and Redeveloping Public Housing in Chicago." PhD diss., Graduate School of Arts and Sciences of the Columbia University, New York City.

Ginocchini, G., and C. Manaresi, eds. 2008. "Bologna, a New Plan." Urbanistica 135: 44-91

Graham, S. 2010. Cities Under Siege: The New Military Urbanism. London: Verso.

Hansen, K. N. 2004. The Greening of Pentagon Brownfields: Using Environmental Discourse to Redevelop Former Military Bases. Lanham: Lexington Books.

Healey, P. 1997. Collaborative Planning: Shaping Places in Fragmented Societies. London: MacMillan.

Healey, P. 2003. "Collaborative Planning in Perspective." Planning Theory 2 (2): 101-123.

Healey, P. 2007. Urban Complexities and Spatial Strategies. Towards a Relational Planning for Our Times. London: Routledge.

Healey, P. 2010. Making Better Places. The Planning Project in the Twenty-First Century. London: Palgrave Macmillan.

Healey, P., and R. Upton, eds. 2010. Crossing Borders. International Exchange in Planning Practice. London: Routledge.

Hill, C. 2000. "Measuring Success in the Redevelopment of Former Military Bases: Evidence from a Case Study of the Truman Annex in Key West, Florida." Economic Development Quarterly 14 (3): 267-277.

Holman, B. W. 2001. Military Base Closure: Overview of Economic Recovery, Property Transfer and Environmental Clean up GAO-d011054t. Washington, DC: United States General Accounting Office.

Huxley, M., and O. Yiftachel. 2000. "New Paradigm or Old Myopia? Unsettling the Communicative Turn in Planning Theory." Journal of Planning Education and Research 19 (4): 333-342.

Innes, J. 1995. "Planning Theory's Emerging Paradigm: Communicative Action and Interactive Practice." Journal of Planning Education and Research 14 (3): 183-190.

Innes, J. 1996. "Planning Through Consensus Building." Journal of American Planning Association 62 (4): $460-472$.

Innes, J., and D. Booher. 1999. "Consensus Building as Role Playing and Bricolage: Toward a Theory of Collaborative Planning." Journal of American Planning Association 65 (1): 9-26.

Mazza, L. 2004. Piano, Progetti, Strategie. Milan: Franco Angeli.

Palermo, P. C., and D. Ponzini. 2010. Spatial Planning and Urban Development. Critical Perspectives. Dordrecht: Springer.

Palermo, P. C., and D. Ponzini. 2012. "At the Crossroads between Urban Planning and Urban Design: Critical Lessons from Three Italian Case Studies." Planning Theory and Practice 13 (3): 445-460.

Parlato, S., and G. Vaciago. 2002. "La dismissione degli immobili pubblici. La lezione del passato e le novità della legge n. 410, 23 Novembre 2001." Quaderni Ricerche per l'Economia e la Finanza 8: 3-27.

Pasqui, G. 2010. "Un ciclo politico al tramonto: perchè l'innovazione delle politiche urbane in Italia ha fallito.” XXIV Convegno SISP, Venice. 
Pasqui, G. 2012. "Il Master Plan per le aree militari di Piacenza. Processo, attori e forme di conoscenza." Territorio 62: 58-63.

Pasqui, G., S. Armondi, and V. Fedeli. 2010. "I piani strategici alla prova." In 10 anni di pianificazione strategica in Italia. Ragioni esiti e criticità, edited by R. Florio,. $3^{\circ}$ Quaderno Recs. Florence: Bandino.

Ponzini, D. 2008a. Il Territorio dei beni culturali. Interpretazioni strategiche del processo di privatizzazione dei beni e delle attività culturali in Italia. Rome: Carocci.

Ponzini, D. 2008b. "La valorizzazione degli immobili statali come opportunità di sviluppo territoriale." Urbanistica 136: 87-94.

Ponzini, D. 2008c. "New Italian Perspectives on Urban Planning: A Policy Tool Approach." Planum December: $1-31$.

Ponzini, D. 2010. "The Process of Privatisation of Cultural Heritage and the Arts in Italy: Analysis and Perspectives." International Journal of Heritage Studies 16 (6): 508-521.

Ponzini, D., and M. Vani. 2012. "Immobili militari e trasformazioni urbane: Visioni ed esperienze italiane ed europee." Territorio 62: 13-18.

Sager, T. 1994. Communicative Planning Theory. Aldershot: Aldervebury Press.

Sorenson, D. S. 1998. Shutting Down the Cold War: The Politics of Military Base Closure. New York: St Martin Press.

Szelinski, B. 1997. "Environmental Contamination and Remediation Practices at Former and Active Military Bases: German Experiences.” NATO Science Series 2 Environmental Security 48: 1-12.

Tewdwr-Jones, M., and P. Allmendinger. 1998. "Deconstructing Communicative Rationality: A Critique of Habermasian Collaborative Planning." Environment and Planning A 30 (11): 19751989.

Van Driesche, J., and M. Lane. 2002. "Conservation Through Conversation: Collaborative Planning for Reuse of a Former Military Property in Sauk County, Wisconsin, USA." Planning Theory \& Practice 3 (2): 133-153.

Vettoretto, L. 2003. "Deliberazione come pratica e come procedura: Limiti degli attuali orientamenti nelle teorie comunicative del planning." Critica della Razionalità Urbanistica 14: 79-88.

Warf, B. 1997. "The Geopolitics/Geoeconomics of Military Base Closures in the USA." Political Geography 16 (7): 541-563.

White, S. C. 1996. "Depoliticising Development: The Uses and Abuses of Participation." Development in Practice 6 (1): 6-15.

Zimmer, V. 2004. "Conversion of the US Bases in the Philippines: Strategies of Compensation in Regional Economies Dominated by the Military.” Geographica Helvetica 2004 (1): 20-29. 